Revista General de Información y Documentación ISSN: 1132-1873

\title{
Costes, salarios y precios en el Libro de cuentas de Pedro Blusón y Juan Francisco Larumbe, Huesca, 1625-1642: análisis de precios y costes en una imprenta en el Siglo de Oro
}

\author{
Manuel José Pedraza Gracia ${ }^{1}$
}

Recibido: 6 de noviembre de 2020 / Aceptado: 8 de diciembre de 2020

Resumen. Se analizan los costes de producción del impreso, los salarios de los trabajadores en la imprenta y los precios de venta de los productos impresos en la imprenta de Pedro Blusón y de Juan Francisco Larumbe en Huesca entre 1625 y 1642. Se utiliza como fuente el libro de contabilidad más antiguo conservado en España, el Libro de cuentas de Pedro Blusón y Juan Francisco Larumbe (Archivo Histórico Provincial de Huesca, F. 48).

Palabras clave: Blusón, Pedro; Larumbe, Juan Francisco; Huesca; S. XVII; Costes; Salarios; Precios; Imprenta.

\section{[en] Costs, Wages and Prices in the Libro de cuentas de Pedro Bluson y Juan Francisco Larumbe, Huesca, 1625-1642: Price and Cost Analysis in a Printing House from the Spanish Golden Age}

\begin{abstract}
This work analyses the production costs of printing, the wages of the workers employed in the press and the selling prices of the products printed in Pedro Blusón's and Juan Francisco Larumbe's workshops in Huesca between 1625 and 1642, using as a source the oldest accounting book preserved in Spain, the Libro de cuentas de Pedro Blusón y Juan Francisco Larumbe (Archivo Histórico Provincial de Huesca, F. 48).
\end{abstract}

Keywords: Blusón, Pedro; Larumbe, Juan Francisco; Huesca (Spain); 17th century; Costs; Wages; Prices; Printing.

Sumario. 1. Introduccion. 2. Los costes. 3. Los recursos humanos. 4. Las ventas en el libro de cuentas. 5. A modo de conclusión. 6. Referencias bibliográficas.

Cómo citar: Pedraza Gracia, M.J. (2020) Costes, salarios y precios en el Libro de cuentas de Pedro Blusón y Juan Francisco Larumbe, Huesca, 1625-1642: análisis de precios y costes en una imprenta en el Siglo de Oro, en Revista General de Información y Documentación 30 (2), 549-572.

1 Universidad de Zaragoza. Departamento de Ciencias de la Documentación

E-mail: pedraza@unizar.es 


\section{Introduccion}

El Libro de cuentas de Pedro Blusón y Juan de Larumbe (Archivo Histórico Provincial de Huesca -AHPHU-, F. 48) es un documento de 167 folios excepcional para la historia de la imprenta en la ciudad aragonesa, pero que en muchos aspectos trasciende ese ámbito, siendo el más antiguo relacionado con la imprenta localizado hasta la fecha en España. ${ }^{2}$ Aunque su intención fue, seguramente la de servir de apoyo a la actividad empresarial de Pedro Blusón continuada por Juan Francisco Larumbe, entra mucho mejor dentro de la tipología de los denominados «libros de cuenta y razón» (Mouysset, 2007) que, a su vez, se han clasificado entre los llamados «egodocumentos» (Dekker, 2002). Podría decirse que, más que el «libro de cuentas» de una empresa impresora, es el libro de un empresario que refunde en este documento parte de aquellos datos económicos y laborales que interesan a los negocios y a la economía familiar, lo que es lógico en una sociedad en la que ambos ámbitos se entrelazan y confunden con tanta naturalidad como frecuencia. Sin ser demasiado ambicioso, por la cantidad de datos que contiene es, como se ha dicho, el más antiguo de este tipo conservado sobre la imprenta hispana. Es también singular por tratarse de un libro que, afectando a la misma casa impresora y sirviendo con la misma o similar finalidad a dos impresores diferentes, que mantienen perspectivas empresariales y profesionales y, por consiguiente, actividades no exactamente idénticas, acaban, a través de su esposa, formándo parte, aparentemente, de un mismo núcleo. Además, no existe duda sobre su veracidad, puesto que son datos contables.

Las anotaciones se inician en 1625 y continúan sin interrupción hasta 1542. Aunque en 1653 y 1654 se incluyeron algunos apuntes sobre adquisición de libros por parte de Larumbe, desde 1654 hasta 1684 solamente anotó algunos albaranes relacionados con la contabilidad familiar. El libro será continuado con esta misma función por su sucesor, José Lorenzo de Larumbe, desde 1684. La información existente, aunque valiosa, no es ni se puede considerar íntegra, ya que, como se reconoce en el propio Libro había, al menos, otro similar, ${ }^{3}$ por lo que no debe extrañar esta perspectiva parcial.

2 El referente internacional más antiguo es el manuscrito Zornale, o libro diario de Francesco de Madiis. University of Oxford (2019). El proyecto, dirigido por Cristina Diondi ha dado ya a conocer algunos resultados: Cristina Dondi and Neil Harris, «Oil and Green Ginger. The Zornale of the Venetian Bookseller Francesco de Madiis, 1484-1488», en Documenting the Early Modern Book World: Inventories and Catalogues in Manuscript and Print, Acts of the Third St Andrews Book Group Conference. 7-9 July 2011, edited by Natasha Constantinidou and Malcolm Walsby, Leiden, Brill, 2013, pp. 341-406; «Best Selling Titles and Books of Hours in a Venetian Bookshop of the 1480s: the Zornale of Francesco de Madiis», La Bibliofilía, 115 (2013), pp. 6382; «Exporting books from Milan to Venice in the 15th century: evidence from the Zornale of Francesco de Madiis», La Bibliofilía, n. 1-3, 116 (2014), pp. 121-148; y «I romanzi cavallereschi nel Zornale di Francesco de Madiis (1484-88): profilo merceologico di un genere», en Carlo Magno in Italia e la fortuna dei libri di cavalleria. Atti del Convegno internazionale, Zurigo, 6-8 maggio 2014, a cura di Johannes Bartuschat e Franca Strologo, Ravenna, Longo, 2016, pp. 251-299.

3 F. 81r. 
Las anotaciones se pueden dividir, sin estridencias en tres grupos:

a) Relacionadas con la actividad profesional.

b) Relacionadas con los gastos y deudas de la familia.

c) Relacionadas con noticias familiares.

En este trabajo se estudian los datos que, procedentes de ese primer grupo, aportan información sobre precios, salarios y gastos relacionados con la imprenta y la producción de impresos.

Lógicamente, en el documento se usa el sistema aragonés de pesos y medidas por lo que es menester tener muy presente el especial sistema monetario aragonés (Tejeda, 1546; Lara, 1984) ${ }^{4}$ y el de peso (Lara, 1984, pp. 76,78, 109). ${ }^{5}$ También se emplea el sistema de medida del papel, ${ }^{6}$ que, por el contrario, es de uso común.

\section{Los costes}

Todas las actividades que se realizaban en la imprenta tenían un coste (Moll, 2003). Era imprescindible la provisión de la materia prima, el papel, que solía ser aportado por el editor; la disposición de fundiciones o pólizas suficientes en la imprenta y tacos xilográficos, que definían la variedad y calidad de los productos bibliográficos; y los materiales para elaborar la tinta. Además era trascendental el material humano, que aportaba experiencia y calidad.

Por consiguiente y en esencia, se pueden dividir los recursos necesarios para imprimir un libro en dos grupos: los materiales y los humanos. Todos estos recursos tenían un coste de adquisición, de producción o de mantenimiento y, por supuesto, de transporte, porque los recursos materiales no se encuentren siempre próximos al lugar de producción y se hace imprescindible recurrir a transportistas que hagan llegar las mercancías que se necesitan, y hagan llevar las que se producen a su destino, además de transportar al propio impresor en sus viajes para negociar la provisión de materias primas, la impresión de libros o la entrega de trabajos ya realizados, entre otras actividades. La ubicación de Huesca a estos efectos es óptima, ya que se encuentra en el camino real que llevaba desde Zaragoza a Francia, pasando por Huesca, Jaca, Ayerbe y Canfranc, siguiendo el eje sur-norte y siguiendo el eje oeste-este se situaba en el camino que unía el norte de Navarra (Pamplona) con

$4 \quad 12$ ds. (dineros jaqueses) = 1 s. (sueldo dinero jaqués). El sueldo es la unidad de medida y equivale a 32 mrs. (maravedíes).

24 ds. = 2 ss. = 1 r. (real). El valor sería algo menos del doble del $\mathrm{r}_{\mathrm{c}}$ (real castellano) que equivalía a 34 mrs.

240 ds. $=20$ ss. $=10$ rs. $=1$ Libra $(£)=1$ Escudo.

$5 \quad 1$ Libra $(£)=0$ '35 kg.

$9 £=1$ cuarterón $=3,15 \mathrm{~kg}$

1 arroba (@)= 4 cuarterones = 36 £=12,6 kg

1 quintal=4@=16 cuarterones=144£=50,4 kg

Pero: En Castilla $1 @_{\mathrm{c}}=26 £_{\mathrm{c}}=11,50 \mathrm{Kg}$ y $1 £_{\mathrm{c}}=0,46 \mathrm{~kg}$.

625 pliegos $=1$ Mano.

500 pliegos $=20$ manos $=1$ Resma.

5000 pliegos $=200$ manos $=10$ resmas $=1$ Bala. 
Cataluña (Lérida y Barcelona), pasando en Aragón, además, por Barbastro y Monzón. Sin embargo, el Libro de cuentas únicamente menciona Zaragoza y Barbastro, quizás por ser las localidades más próximas.

\subsection{El transporte}

Los profesionales del transporte ${ }^{7}$ mueven tanto materiales de todo tipo como personas, incluido el propio impresor o su familia, en sus viajes, en este caso, a Zaragoza.

En 1625 Blusón cita dos viajes, en 1628, tres, y en 1631 uno más. Juan Francisco Larumbe documenta solamente dos en 1636. También viaja en este mismo año a Zaragoza Paciencia López, viuda de Blusón y, posteriormente, esposa de Juan Francisco Larumbe, con una criada. ${ }^{8}$ Queda patente que cierto número de desplazamientos eran necesarios. El trayecto de los $75 \mathrm{~km}$ costaba $8 \mathrm{ss}$. por persona.

En cuanto a las mercancías, el coste del transporte de 1@ de peso era de 16 ds (1 s. y 4 ds $)^{9}$ y, como además era necesario fijar la mercancía lo más firmemente posible, se necesitaban cuerdas resistentes. En el transporte de los 474 ejemplares de la edición de las Resoluciones morales de Antonio Diana, ${ }^{10}$ algo menos de media tonelada de libros (39 @ y un cuarterón, 494,55 kg) distribuida en 9 balas, se gastaron 8 ss. en cuerdas y el precio del envío ascendió a 52 ss. y 4 ds. El coste total del envío de obra de Diana a Zaragoza fue de 60 ss. y 4 ds. Lo que supuso un coste añadido por ejemplar de 1,5 ds.

En este mismo año de 1637 Larumbe confecciona una relación de las mercancías que ha trasportado el carretero Juan Clos. ${ }^{11}$ De esta relación se obtienen una serie de informaciones sobre el coste de determinadas mercancías:

$1^{\circ}$. El transporte de 16 balas y media de papel (82.500 pliegos) en doce viajes diferentes, permite deducir que el coste de transporte por bala de papel es de $4 \mathrm{ss} .{ }^{12}$

$2^{\circ} .3$ docenas de pergaminos en dos viajes, costaron a 6 ds. la docena.

$3^{\circ}$. 3 paquetes de papel impreso tuvieron un coste de $1 \mathrm{~s}$. y 4 ds. por paquete, lo que lleva a suponer que cada paquete debía tener el peso aproximado de $1 @$.

Los impresores oscenses trabajan con tres carreteros principalmente: Juan Pecaz (Ff. 17r-18r) y su yerno, Pedro Burruel (Ff. 2r, 4r, 5r, 18r-18 v, 46 v) y con Juan de Clos (F. 17 v., 107v).

8 Ff. 46v-47r.

9 Se pagan por cargas de la trementina, por transportar el usillo y la matriz de la prensa, y en el segundo y tercer viaje de pólizas nuevas (f. 46r) y otros muchos. Hay alguna excepción en la que se llega a los 17 ds. (1 s., 5 ds.) que se pagan en el primero de los envíos de fundiciones. El día 15 de septiembre de 1650 en Madrid, Miguel Hernández y Martín Vela, carreteros de bueyes, contratan el transporte de trapo para el molino de papel de Rafael López en La Cabrera por 48 maravedís (1 ss. y 6 ds.) la @. AHPM, Protocolo 8655, ff. 455v-456r (Agulló, 2009, doc. 6M, p. 1740).

10 Antonino DiANA, Antonini Diana panormitani Clerici Regularis ... Resolutionum moralium pars tertia in qua selectiores casus conscientiae ... sub his tractatibus explicantur ... habet haec editio caesaraugustana quam plura ab authore addita, necnon \& indicem rerum, qui in alijs editionibus desideratur, Osca, apud Patientiam Lopez, viduam Petri Bluson ..., 1635.

11 Ff. $46 r-47$ r.

12 Ff. $46 r-47$ r. 


\subsection{Los recursos tipográficos}

El principal recurso tipográfico de la imprenta eran las fundiciones o pólizas, esto es, el conjunto de tipos de un único cuerpo y diseño. El precio de las pólizas se fijaba según el peso del conjunto de tipos que las componían, que no era fijo, ya que el número de tipos de cada suerte -con la misma representación- era fijado por el impresor y no por el fundidor. ${ }^{13}$

Por la fundición de una «atanasia redonda» ${ }^{14}$ se pagaron 150 rs. (300 ss.). ${ }^{15}$ Para esta fundición se entregaron 2 @ menos $8 £$, esto es $64 £(22,4 \mathrm{~kg})$, de «metal sucio». ${ }^{16}$ Solo el peso de las suertes de caja baja de esta «atanasia redonda» supuso 4’5 @ (57,5 kg). ${ }^{17}$ En el último de los envíos de metal sucio se añadieron 50 rs. (100 ss.) como pago de una fundición de «cícero». ${ }^{18}$ Aunque las anotaciones no dejan claro este particular, parece que para esta fundición Pedro Blusón había entregado a Pedro Gel, además, otros 50 rs (100 ss.) que le dio por medio del impresor de Zaragoza Diego de la Torre (Velasco, 1998, pp. 173-177) y otros 7 escudos (140 ss.) que le entregó por medio del impresor zaragozano Juan Bares, ${ }^{19}$ que hacen un total de $17 £$ (340 ss.). A pesar de lo cual todavía le adeudaba 127 rs. $\left(254\right.$ ss.). ${ }^{20}$ El coste total de esta fundición fue, por tanto, de 594 ss.

Al precio de las fundiciones había que añadir el coste del trasporte del metal sucio desde Huesca hasta Zaragoza y el de llevar las fundiciones nuevas a Huesca. El 26 de enero de 1625 Pedro Blusón pasa cuentas con el carretero Juan de Pecaz ${ }^{21}$ En las que se cita que le ha traído $24 £$ (50,4 kg) de letra nueva de fornitura, para cuyo pago debe destinar 1 r. (2 ss.).

Además de los tipos de imprenta, el taller precisaba de otra clase de recursos tipográficos para el ejercicio de su labor. En cualquier imprenta eran esenciales los tacos xilográficos o las planchas de cobre, si había tórculo, o ambos, para poder ilustrar los libros y, frecuentemente, para la realización de estampas. Solamente una referencia a este tipo de recursos aparece en el Libro de notas: en 1631 Pedro Blusón reconoce haber efectuado el pago de 100 rs. (200 ss.) como último plazo de las tablas para imprimir imágenes de Nuestra Señora del Pilar de Caragoça y otra de Nuestra

13 En el caso de la póliza de breviario que adquiere Pedro Blusón, por ejemplo, estaba compuesta de 6.000 tipos, según se ha documentado. F. 1r.

14 Tomando como medida el punto Fournier, su medida sería de 4,55 mm.

15 F. 2 r.

16 Para la fundición de un tipo se reciclaban tipos viejos, desgastados o en desuso, a los que siempre había que añadir una pequeña cantidad de metal nuevo. F. 3r.

17 F. 3v. El pesaje se realiza delante de tres testigos, el guantero Juan Casaña y los impresores de la casa tipográfica oscense Sebastián Pérez y Lorenzo Pelegrín. En esa anotación se hace mención a otras fundiciones. Además de la de «atanasia redonda» se citan una de «atanasia cursiva» y una de «breviario redondo» (más o menos unos 3,15 mm). En 1612 la «atanasia» que tenía en el taller madrileño de Miguel Serrano de Vargas pesó $8 @$ c $(92$ kg), esto es 7@y $11 £$ (Agulló,2009, p. 92/1743).

18 4,2 mm aproximadamente. En esta fundición se emplean 4 @ y 28 £ (60,32 kg) de metal sucio. F. 4r.

19 Juan Bares había nacido como Pedro Gel en Lestelle, por lo que no es de extrañar que actúe como intermediario entre Blusón y Gel. Vivía en la cuchillería, en la parroquia de La Seo y alternaba su oficio de impresor con el de maestro de hacer enfriadores de corchos. Aunque no se conoce ningún impreso firmado por él está documentado en un contrato de aprendizaje el 18 de febrero de 1626 (Velasco, 1998, pp. 69-70).

20 F. 5 r.

21 F. 17 r. 
Señora de Monserrate cuyo coste fue de $20 £$ (400 ss.), ${ }^{22}$ mucho más económicas que las planchas de cobre para imprimir calcografía. ${ }^{23}$

\subsection{El papel}

El principal gasto de la imprenta, excluyendo el del personal, era el de la materia prima más empleada, el papel (Hidalgo, 2015).

La localidad de Villanueva de Gállego poseía algunos molinos papeleros desde el siglo XV que proveían de papel a las imprentas, el llamado "papel de la tierra». ${ }^{24}$ Villanueva de Gállego se encontraba en el camino real que discurría entre Zaragoza y Huesca, aproximadamente a 16 kilómetros de Zaragoza y a unos 60 kilómetros de Huesca.

El Libro de cuentas no aporta información de todo el papel usado en la imprenta. Entre 1625 y 1632, en diversas tandas llega papel de la tierra hasta un total de 128 resmas y media (64.250 pliegos). Y solo durante 1637 Larumbe recibe doce portes de papel que suman 16 balas y media (82.500 pliegos). ${ }^{25}$

Aunque parece una cantidad enorme, hay que tener en cuenta que una edición de 1.000 ejemplares de un libro en $4^{\circ}$ de 400 páginas, esto es de 50 pliegos consumiría un total de 50.000 pliegos. También hay que tener presente que la impresión de un pliego al día de esta supuesta edición aún estaría muy lejos de la producción normal de una imprenta que debería estar entre los 1.500 pliegos impresos diarios, lo que se denominaba «jornada castellana», y los 1.750 .

A este ritmo de producción (1.500 pliegos diarios) los 82.500 pliegos cubrirían tan solo el consumo de papel de 55 días, poco más de dos meses de 26 jornadas mensuales.

De la documentación se deduce que el papel que proporciona un papelero llamado Quintana valía por resma (500 pliegos) 14 ss. (Velasco, 1998, pp. 52, 77, 79, 133, 160) Es fácil suponer que el coste total de las 20 resmas que envía a Huesca sería el resultado de sumar los 280 ss. del coste del papel y los 3 rs. (6 ss.) de su transporte, esto es 286 ss.

En $1632{ }^{26}$ Beltrán Domech provee de papeles que podrían se denominar «especiales». El papel que Pedro Blusón adquiere a Domech en tres tandas es el siguiente:

14 resmas (7.000 pliegos) a 23 ss. -quizás de marca mayor o marquilla- la resma que hacen $16 £$ y 2 ss. (322 ss.). ${ }^{27}$

22 F. 25v.

23 En 1627 los Diputados del Reino de Aragón pagan 800 ss. por una lámina (Velasco, 1998, pp. 49-50).

24 Esta denominación se aplica en casi todas las imprentas al referirse al papel fabricado en los molinos hispanos más próximos al taller (Agulló, 1974, 2; Lucía, 2006, p. 221). Se relacionan dos contratos de 1621 y 1622 en los que la resma de papel de los molinos de El Paular se vende a $11 \mathrm{rs}_{\mathrm{c}}$ (11 ss. y 8 ds., aproximadamente), pero el precio del mismo oscila (ya convertido a moneda aragonesa) entre los 10 ss. y 10 ds. (1627) y los 18 ss. y 1 d. (1648) (Agulló, 2009, docs. U 493, D 567, D 2079, U 2294).

25 Ff. 46r-47r.

26 F. $121 \mathrm{v}$.

27 En 1627 se adquieren en Zaragoza 36 resmas de papel marquilla a 23 rs. la resma (Velasco, 1998, pp. 49-50). 
8 resmas (4.000 pliegos) de papel de Génova a 10’5 rs. (21 ss.) la resma -quizás de marca común-), esto es 168 ss.

8 resmas (4.000 pliegos) de papel de Génova que a 22 rs. (44 ss.) -quizás de marca mayor o marquilla-) valen $17 £$ y 12 ss. (352 ss.). ${ }^{28}$

En fecha no indicada Larumbe reconoce una deuda con Martín de Estallo menor por 12 resmas (6.000 pliegos) de papel de Cataluña a 15 ss. la resma. ${ }^{29}$

Como puede observarse, estos papeles especiales ${ }^{30}$ tienen un coste muy variable, pero siempre superior al que tenía el papel de la tierra.

Se utilizaban para documentos de cierto valor como las conclusiones y los diplomas. También se emplean tafetanes para la impresión de conclusiones como sistema de obtener un impreso mucho más lujoso, cuyo coste es de 2 sueldos por unidad.

28 La diferencia de precio entre las dos remesas de papel genovés podría estar justificada por el distinto tamaño del mismo. Pero no se documenta este aspecto. El papel marquilla se adquiere en 1608 y 1673 en Madrid a 60 mrs. y a $2 \mathrm{rs}_{\mathrm{c}}$ la mano y en la segunda fecha el de marca mayor a $4 \mathrm{rs}_{\mathrm{c}}$, que convertidos a ss. por resma serían, respectivamente 18 ss. y 8 ds., y 21 ss y 3 ds. la resma de marquilla y 42 ss y 6 ds. cada resma de marca mayor (Agulló, 2009, docs. D 1936 y D 1.937).

29 F. 105r. Papel de Gerona llega a Zaragoza en 1608 y en 1610 a 17 ss. la resma, pero al ser comprado por instituciones del Reino de Aragón, se libera el envío del pago de los derechos del General (Velasco, 1998, p. 52).

30 En Zaragoza se ha documentado la adquisición de papel de Pisa para la impresión de: Juan BRIZ MARTíNEZ, Historia de la fundacion, y antiguedades de San Iuan de la Peña, y de los reyes de Sobrarue, Aragon, y Nauarra ... diuidida en cinco libros, En Çaragoça, por Iuan de Lanaja y Quartanet, impressor del reyno de Aragon, y de la Vniversidad, 1620, en 1619 a 18 ss. la resma; y de papel francés en 1612 por 17 ss. y en 1647 para la impresión de: Juan Francisco ANDrÉs DE UzTÁRRoz, Vida de San Orencio Obispo de Aux ... translacion de sus reliquias a la ciudad de Huesca ... i de las de S. Orencio i S. Paciencia sus gloriosos padres al monasterio de San Orencio de la ciudad de Aux ..., En Zaragoça, por Pedro Lanaja, y Lamarca, ..., 1648, por 18 ss (Velasco, 1998, p. 52). En Madrid se comercia también con otros papeles diferentes: «Cuenca, a cuyo frente estuvieron durante estos siglos los Otonel; los de La Adrada (Ávila); Almonacid de Zurita (molino que llamaban de Badux o Badujo); La Cabrera (Sigüenza), al que llamaban de Los Heros; los de Valdetorres y Silillos; Arco y Palazuelos (Segovia) y Beteta (Cuenca)», algunos de cuyos precios se han convertido a moneda aragonesa: de Cuenca en 1643, a 4 ss. y 10 ds., de La Adrada en 1654 a 14 ss. y 10 ds. y de La Cabrera en el mismo año a 17 ss. y 6 ds. (Agulló, 2009, p. 150/1743). 
Tabla 1. Costes de transporte, recursos tipográficos y materias primas

\begin{tabular}{|c|c|c|}
\hline Tipo & Precio & Precio en ss. \\
\hline \multicolumn{3}{|c|}{ Transporte } \\
\hline Transporte de personas ${ }^{31}$ & $8 \mathrm{ss}$ & $8 \mathrm{ss}$ \\
\hline Transporte de mercancías en general $^{32}$ & $1 \mathrm{~s} \mathrm{y} 4 \mathrm{ds}$ & $1 \mathrm{~s}$ y $4 \mathrm{ds}$ \\
\hline Transporte de papel (bala de papel) ${ }^{33}$ & $4 \mathrm{ss}$ & $4 \mathrm{ss}$ \\
\hline Transporte de papel (paquete) ${ }^{34}$ & $1 \mathrm{~s} \mathrm{y} 4 \mathrm{ds}$ & $1 \mathrm{~s} \quad \mathrm{y} 4 \mathrm{ds}$ \\
\hline Transporte de pergamino (docena) ${ }^{35}$ & $6 \mathrm{ds}$ & $6 \mathrm{ds}$ \\
\hline \multicolumn{3}{|c|}{ Recursos } \\
\hline Fundición de Atanasia redonda ${ }^{36}$ & 150 rs & 300 ss \\
\hline Fundición de cícero ${ }^{37}$ & 227 rs y 7 escudos/£ & 594 ss \\
\hline Taco xilográfico para estampas ${ }^{38}$ & $20 \mathrm{~L}$ & 400 ss. \\
\hline \multicolumn{3}{|c|}{ Materias primas } \\
\hline Resma (papel de la tierra) ${ }^{39}$ & 14 ss. & 14 ss. \\
\hline Resma (papel especial -marca mayor-) & 23 ss & 23 ss \\
\hline Resma (papel de Génova -marca común-) ${ }^{41}$ & 10,5 rs & $21 \mathrm{sS}$ \\
\hline Resma (papel de Génova -marca mayor-) ${ }^{42}$ & 22 rs & $44 \mathrm{ss}$ \\
\hline Resma papel de Cataluña ${ }^{43}$ & $15 \mathrm{ss}$. & $15 \mathrm{ss}$ \\
\hline Tafetán (unidad) & 2ss & 2 ss \\
\hline
\end{tabular}

\section{Los recursos humanos}

En un taller con una prensa sería suficiente con la presencia de un cajista, que bien podría ser el propietario de la misma, un tirador y un batidor. En estas imprentas pequeñas, las labores se superponen y entremezclan, quedando muy difuminadas. Cierto es que el trabajo del cajista, es muy especializado y el de los oficiales de la prensa también, pero el resto de las labores: humectación del papel, tendido, alzado, almacenamiento, preparación de la tinta... se distribuirían en función de las necesidades, de los conocimientos y de la disposición del maestro de la imprenta, del personal y del resto de la familia del impresor. Durante las tareas de impresión, por ejemplo, sería frecuente que el autor, el cajista, o el maestro, si no tenía un trabajo asignado, se encargaran de la corrección de las pruebas que se irían corrigiendo

F. $46 v-47 r$.

Ibídem.

Ibídem.

Ibídem.

Ibídem.

F. 2r.

F. $4 \mathrm{r}$.

F. $25 \mathrm{v}$.

F. 18r.

F. 121r

Ibídem.

Ibídem.

43 F. $105 r$.

44 F. 101v. 
conforme se imprimían. Una vez impreso un pliego, se procedería a su alzado y a su almacenamiento, mientras se culminaba la labor administrativa y de control.

El Libro de cuentas recoge con bastante claridad las notas económicas derivadas de las relaciones laborales con los diferentes trabajadores de la imprenta. De estas anotaciones se desprende que el contratante se obligaba a pagar un salario fijo mensual, a dar de comer, a proporcionar habitación y a limpiar la ropa del trabajador. En periodos específicos, que se pactaban preferentemente de manera semestral o anual, se pasaban cuentas, puesto que frecuentemente se hacían adelantos en especie y metálico en función de las necesidades cotidianas del trabajador.

El cajista, Juan Nogués contrata su trabajo en 1637 por una salario mensual de 40 ss. y en el año siguiente por un $75 \%$ más, 70 ss. Esto vendría a indicar que la primera contratación se tomaría a modo de prueba hasta demostrar la pericia del oficial, ya que es frecuente que los primeros contratos de un trabajador estén peor pagados que los siguientes. De hecho, ocurre algo similar con el salario del tirador Miguel Ferrer, que se establece en 1637 en 20 ss., una cantidad notablemente baja.

Para los cajistas, en un periodo de tan solo un año, va desde los 40 hasta los 70 ss., aunque hay otros dos salarios de 60 ss.: de Jusepe Ruiz en 1635 y de Vergés en 1638. Se podría decir que el salario de un cajista en esta época se establecía en torno a los 60 ss. y que un buen cajista podría obtener un salario algo superior, llegando a los 70 . El jornal de los tiradores tiene el mismo caracter variable que se ha observado para los cajistas. Entre 1625 y 1635 el salario de un tirador-batidor se establece también en torno a los $60 \mathrm{ss} .{ }^{45}$ Los dos tiradores que trabajaron previamente con Blusón, son contratados por Larumbe por 70 ss. mensuales cada uno, aunque ambos desaparecen de la imprenta en ese mismo año. En marzo de 1637 Miguel Ferrer cobra 20 ss., si bien aparace citado por última vez en junio, y Miguel Pueyo 50 ss. Tan solamente dos años después, Juan de San Martín cobra 64 ss. mensuales.

45 Soler, f. 81r; Castañ, f. 74r/75v; Pelegrín 90r/94r, 99r/99v; Vera 95r. 
Tabla 2. Salarios mensuales de tiradores/batidores y cajistas (1630-1639)

\begin{tabular}{|c|c|c|c|}
\hline Nombre & Fecha & Salario & Salario en ss. \\
\hline \multicolumn{4}{|c|}{ Tiradores/batidores } \\
\hline Pedro Soler ${ }^{46}$ & 1630 & $60 \mathrm{ss}$ & $60 \mathrm{ss}$ \\
\hline Enrique Castañ ${ }^{47}$ & $1627 / 1629$ & $60 \mathrm{ss}$ & $60 \mathrm{ss}$ \\
\hline Lorenzo Pelegrín $^{48}$ & 1630 & $60 \mathrm{ss}$ & $60 \mathrm{ss}$ \\
\hline Lorenzo Pelegrín ${ }^{49}$ & 1636 & 35 rs & $70 \mathrm{ss}$ \\
\hline Pollart ${ }^{50}$ & 1630 & 24 rs & 48 ss. \\
\hline Pollart ${ }^{51}$ & 1630 & 30 rs & 60 ss. \\
\hline Tomás Vera ${ }^{52}$ & 1631 & 20 rs & 40 ss \\
\hline Tomás Vera ${ }^{53}$ & 1631 & 25 rs & $50 \mathrm{ss}$ \\
\hline Tomás Vera ${ }^{54}$ & 1632 & $30 \mathrm{rs}$ & $60 \mathrm{ss}$ \\
\hline Tomás Vera ${ }^{55}$ & 1636 & 35 ss & $70 \mathrm{ss}$ \\
\hline Miguel Ferrer ${ }^{56}$ & 1637 & 10 rs. & $20 \mathrm{ss}$ \\
\hline Miguel Pueyo ${ }^{57}$ & 1637 & 25 rs & $50 \mathrm{ss}$ \\
\hline $\begin{array}{l}\text { Juan de San } \\
\text { Martín }^{58}\end{array}$ & 1639 & 32 rs & $64 \mathrm{ss}$ \\
\hline \multicolumn{4}{|c|}{ Cajistas } \\
\hline Jusepe Ruiz $^{59}$ & 1635 & 30 rs & $60 \mathrm{ss}$ \\
\hline Juan Nogués ${ }^{60}$ & 1637 & 20 rs & $40 \mathrm{ss}$ \\
\hline Juan Nogués ${ }^{61}$ & $1638 / \ldots$ & 35 rs & $70 \mathrm{ss}$ \\
\hline Agustín Verges $^{62}$ & 1638 & 30 rs & $60 \mathrm{ss}$ \\
\hline
\end{tabular}

\section{Las ventas en el libro de cuentas}

Solo algunas producciones bibliográficas salidas del taller han dejado cierto rastro en los apuntes del Libro de cuentas. Por las referencias que figuran en él podrían haberse anotado en el otro libro ${ }^{63} \mathrm{y}$, demás, seguramente muchas de las compraventas y negocios se harían de palabra y al contado y no serían ni siquiera anotados en los libros.

\footnotetext{
F. 81r.

Ff. $74 \mathrm{r} / 75 \mathrm{v}$.

Ff. 90r/94r, 99r/99v.

F. 99r.

F. 101r.

Ibídem.

F. 95r

Ibídem.

Ff. 96r/98r.

F. $98 \mathrm{r}$.

F. 24v.

F. 29r.

Ff. 21r/21v.

F. 73r.

F. $124 \mathrm{r}$.

61 F. $146 r$.

62 F. 28r.

63 F. 81r.
} 


\subsection{Las ediciones propias distribuidas desde el taller}

Una vez analizados los costes es posible establecer los precios de venta, a partir de los acuerdos recogidos en el Libro.

a) En torno a 1633, entre las deudas del librero y editor zaragozano Pedro Alfay y su suegra, Ana del $\mathrm{Bo}^{64}$ con Blusón, se incluye el precio de 0500 Via Crucis de a 15 reales la resma y tiene 8 pliegos y medio que son 8 resmas y media. Valen 12 L., 15 ss. ${ }^{65}$ La estructura material, 8'5 pliegos, revela un librito de tamaño pequeño ${ }^{66}$. El coste de estos 500 Via Crucis es de $12 £$ y 15 ss. (255 ss.), por lo que cada uno costaría algo más de medio sueldo, $6 \mathrm{ds}{ }^{67}$

b) En 1625 entre unas notas sobre las deudas del librero y pergaminero Jacques Borbón figuran: 500 Silvas de Romances. ${ }^{68} \mathrm{Y}$, tras la indicación de la fecha, se anota:

Y el dicho Jaques Borbón tiene por cuenta para venderme 300 Sylvas de romances en papel a 14 pliegos. Devo yo $6 \mathrm{~L}$ y debe el dicho 300 romances de a 14 pliegos cada una de letra de breviario. ${ }^{69}$

Se trata de una obra compuesta con 14 pliegos que, en formato $8^{\circ}$, darían lugar a 112 hojas. Pero aún hay otras notas que citan esta obra:

En 29 de julio de dicho año tomo Martin de Udina, librero y vezino de Huesca, dos resmas y media de Sylvas de romance y otras cosas y lo prometio pagar por San Martin del mismo año. ${ }^{70}$

El librero oscense Martín de Udina retira en 1627 dos resmas y media (1.250 pliegos). Si el libro está compuesto en 14 pliegos, Udina retiraría 90 ejemplares aproximadamente. En este mismo año se relacionan otros 12 ejemplares que, junto con otros libros, le debe el librero de Barbastro Martín Loriente. ${ }^{71}$ Estos doce ejemplares se valoran en 14 ss., por tanto, a $1 \mathrm{~d}$. por pliego impreso, lo que supone que cada ejemplar se estaba vendiendo a $1 \mathrm{~s}$. y 2 ds.

64 Para una aproximación a estos libreros zaragozanos véase Esperanza Velasco (1998).

65 F. 24. A Pedro Alfay se le documenta en Huesca en dos ocasiones: el 27 de noviembre de 1630, nombrando procurador a Sebastián Ponzano, notario causídico. Archivo Histórico Provincial de Huesca (AHPHU), Protocolo de Lorenzo Rasal, 1630, 01368, f. 868r; y el 29 de noviembre de 1633, vendiendo a Ana María Yribarne, viuda de Juan Bernardo Balaguer, jurista, vecino de Huesca un censal de 2.000 ss de propiedad y 100 ss. de pensión que pagan Juan de Nabal y María Campodarbe, cónyuges, vecinos de Huesca, anualmente el 4 de diciembre, por 2.000 ss. AHPHU, Protocolo de Lorenzo Rasal, 1633, 01373, ff. 1.751v-1.752r.

6634 hojas, si estuviese compuesto en formato $4^{\circ}$, 68 hojas en $8^{\circ}$, 82 si en $12^{\circ}$ o 136 si lo fuese en $16^{\circ}$.

67 Ibídem.

68 F. 25.

69 Ibídem.

70 F. 113v. Udina promete pagarle el precio de estos libros que ha recibido el 13 de noviembre, día de San Martín.

71 F. $161 r$. 
De esta manera se llega a la conclusión de que:

- Jacques Borbón debe por sus 500 ejemplares, 583 ss y 6 ds.

- Martin de Udina debe por sus 2,5 resmas, 105 ss.

c) En 1627 y 1628 Pedro Blusón anota una serie de abonos que le ha hecho el mercader de libros y editor zaragozano Felipe Bonilla por la impresión de 900 ejemplares de los Villacastines ${ }^{72}$ que le entregan a Bonilla el 12 de noviembre de 1627. El precio de la impresión se acordó en 16 rs. (32ss.) por cada resma impresa. Cada ejemplar estaba compuesto con 26 pliegos, lo que supone un total de 23.400 pliegos, es decir, 47 resmas menos 4 manos. ${ }^{73}$ Blusón declara que, una vez quitadas las expensas, el coste total de la impresión de la edición quedaba en $75 £$ o 1.500 ss. que sobre 900 ejemplares proporcionan un coste de 1 s y 7 ds., aproximadamente.

d) Hacia 1633, entre las deudas de Alfay se cita un importante número de ejemplares de una edición de unos Destierros de ignorancia $^{74}$ de la siguiente manera:

Mas, 350 Destierros de ignorancia $1^{a}$ parte a 12 pliegos que son todos 8 resmas y media y montan 12 L., 1 ss. $^{75}$

Cada ejemplar vendría a costar unos 8 ds.

e) También en torno a este año de 1633 se anota el último apunte de una edición de Blusón ditribuida por él. De nuevo se haya en el listado de deudas reecnocidas por Pedro Alfay y Ana del Bo: Mas 0500 «Exercicios de fr. Luys» a 14 pliegos a diez y seis reales la resma, valen $22 \mathrm{~L}$., $12 \mathrm{ss}^{76}$

f) En 1637 Larumbe y el doctor Jerónimo de Assín, catedrático de Vísperas de la Universidad oscense, pactan la impresión de un libro que ha escrito. ${ }^{77} \mathrm{El}$ propio autor, como es frecuente en la edición de la época, se encarga del coste de la adquisición del papel que Juan Francisco Larumbe va recibiendo en diversas entregas. Todas estas hacen un total de $33 £$ y 12 ss. (672 ss.) con lo que se adquieren 4 baletas de papel y 8 resmas (48 resmas o 24.000 pliegos). Por consiguiente, el coste de cada resma es de $14 \mathrm{ss}^{78}$ lo que indica que se utilizó papel de la tierra para la impresión.

F. 16v. Tomás de Villacastín, Manual de consideraciones y ejercicios espirituales, para saber tener oración mental, Huesca, por Pedro Blusón, 1627 (Wilkinson y Ulla, 2015, n. 63963), según el ejemplar existente en la Biblioteca nazionale centrale de Florencia. No se conocen por el momento ejemplares en España a tenor de los repertorios más usados.

7347,8 resmas a 32 ss. serían 1.529 ss. y 7 ds. que divididos por 20 ss. que tiene $1 £$ daría un resultado de 76,5 .

74 Alonso de VAsCones, Destierro de ignorancias y aviso de penitentes, En Huesca, por Pedro Bluson ... y a su costa, 1632.

75 F. 24.

76 F. 24.

77 Jerónimo de Assín, Hieronymi de Assin ... In Tit. C. de vsucap. pro empt. commentaria et occasione sumpta totius vsucapionis materiae breuis \& compendiosa pertractatio ...., Oscae, apud Ioannem Franciscum à Larumbe ..., 1638.

78 F. 21v de numeración actual. 
Los trabajos en la prensa se inician el 12 de mayo de 1637 habiéndose pactado la impresión de cada piego en 12 rs. (24 ss.). Para cubrir este gasto Jerónimo Assín entregó un total de $30 £$ (600 ss.). El número de pliegos empleado en la confección de cada ejemplar, excluídos los preliminares, sería de 46 y 3/4. La impresión de estos pliegos a 12 rs. (24 ss.) indica que el coste de la impresión ascendió a 1.122 ss. Finalmente, con los 24.500 pliegos podrían haberse impreso 513 ejemplares.

En un momento posterior Larumbe hace una revisión de cuentas y anota una deuda por parte de Assín derivada del trasporte de 5 baletas de papel, las utilizadas en la impresión, a 20 ss por cada una, lo que haría un montante de 100 ss. A esto suma ciertas encuadernaciones a 2 ss. cada una que ofrecen un total de $1 £$ y 2 ss., esto es 22 ss., con lo que debieron encuadernarse 11 ejemplares.

Tras esta anotación hay otra frustrada: Mas los... y un borrador de diferentes cuentas en las que se anotan las resmas y manos que se han ido imprimiendo y los costes de la impresión. De ellas se desprende que Assín debe a Larumbe:

- $60 £$ y 12 ss. (1.212 ss.) por la impresión de 50 pliegos y cuarto a razón de 12 rs. (20 ss.) por pliego. El total de la edición es de 500 ejemplares.

- de imprimir las 500 láminas calcográficas de la portada, laminas del principio, a 10 ss. el centenar suben $2 £$ y 10 ss. (50 ss.), lo que ha determinado la tirada de la edición;

- del papel que ha faltado, 3 resmas y 15 manos (1.875 piegos) por 7 rs. (14 ss.) la resma, por tanto papel de la tierra, son $2 £$, 2 ss. y 4 ds. (42 ss. y 4 ds.); lo que da para imprimir 3 pliegos y $3 / 4$.

- y por el transporte de 5 balas de papel a 4 ss cada bala, $1 £$ (20 ss.).

- $\quad$ El total de esta deuda asciende, en consecuencia, a $62 £$ y 2 ss. (1.240 ss.). ${ }^{79}$

Puesto que la fórmula colacional de los ejemplares de esta edición es: []$^{1},[\rrbracket]-3[\rrbracket]^{4}, \mathrm{~A}-\mathrm{Z}^{4}, 2 \mathrm{~A}-2 \mathrm{Z}^{4}, 3 \mathrm{~A}^{6}$

Parece evidente que los 3 pliegos y 3/4 mencionados en el listado anterior vendrían a corresponderse con los preliminares del libro y lo mismo ocurre con la lámina con la que se confeccionaría la portada. Esto es:

$\begin{array}{lc}\text { Encuadernaciones } & 22 \mathrm{ss} . \\ \text { Papel } & 672 \mathrm{ss} . \\ \text { Papel preliminares } & 42 \mathrm{ss} . \text { y } 4 \mathrm{ds} . \\ \text { Transporte de papel } & 20 \mathrm{ss} . \\ \text { Impresión } & 1.212 \mathrm{ss} . \\ \text { Láminas } & 50 \mathrm{ss} . \\ \text { Total } & 1.918 \mathrm{ss} . \text { y } 4 \mathrm{ds} .\end{array}$

\footnotetext{
${ }^{79}$ F. 23r de numeración actual.
} 
1.918 ss. vendría a ser el coste de la impresión de 500 ejemplares en $4^{\circ}$ de unas 400 páginas con una ilustración calcográfica en la portada. No es posible conocer los gastos derivados de los procesos administrativos, de elaborar una copia para enviar a revisar para la licencia... ${ }^{80}$ Es decir se conocen los gastos de impresión, que, sin duda, son los más importantes, pero faltan los gastos de edición.

Finalmente, es preciso definir el coste en tiempo de la impresión. Si se comienza a imprimir a mediados de mayo de 1637, los 47 pliegos del texto, suponiendo que se tirasen dos por día de trabajo, 1.000 pliegos diarios impresos en el blanco y la retiración, se pudieron haber tirado en menos de un mes, por lo que la impresión debería estar acabada en junio de 1637. Una vez añadidos los algo mas de 3 pliegos de paratextos preliminares, recibidos todos los permisos administrativos, incluida la licencia de Pedro Fajardo y Requesens, en nombre del Rey, que se firma el 16 de noviembre de 1637, y el resto de preliminares legales, alguno de los cuales se firma en noviembre de 1638, en el pie de imprenta de la edición figura 1638 como fecha de publicación. Por lo tanto, la tramitación y resolución de todo el proceso administrativo llevó casi un año y medio.

g) En 1637 Larumbe pasa cuentas con el impresor, librero y editor zaragozano Pedro Escuer (Velasco, 1998, pp. 356-364) de las que llega a reconocer una deuda de $100 £$ (2.000 ss.). Para pagar esta deuda imprime para él 20 pliegos de la Segunda parte de Diana concertados a 13 reales cada pliego, esto es 520 ss. Por lo tanto, se sabe que en esta fecha se imprimieron en Huesca esos 20 pliegos, pero no se ha podido localizar ninguna edición de la segunda parte de la obra de Antonino Diana, ni en Huesca, ni en Zaragoza. ${ }^{81}$

h) El 10 de junio de 1638 Juan Francisco Larumbe concierta con Juan Biescas la impresión de la segunda parte de su Apología ${ }^{82}$ cuya primera parte ya había sido impresa por Blusón antes de su muerte en 1635, por 26 ss. cada pliego impreso. Esta obra salió de las prensas de Larumbe tres años después. ${ }^{83}$ Desde este momento, en el que el autor le abona $11 £$ (220 ss.) para adquirir papel, hasta el 3 de noviembre, Larumbe anota 7 entregas de la mitad de esta cantidad $5 £$ y 10 ss. (110 ss.). Todas ellas hacen una cantidad de 990 ss. Del conjunto de ingresos que recibe Larumbe, no se puede deducir el coste exacto de la edición porque no solo no se menciona el número de ejemplares de la tirada, sino que solamente se puede llegar saber que Biescas pago, según el Libro de cuentas, 1.450 ss., de los que casi un tercio corresponden a la encuadernación de los 23 ejemplares de la edición ya

80 Solo el gasto de la licencia de impresión ascendía en Zaragoza en 1603 a 104 ss. y a 120 ss. en 1646 (Velasco, 1998, p. 53). A este habría que añadir el gasto de copias manuscritas...

81 Es cierto que se imprime el compendio de la obra realizado por Juan de la Val en 1635 en Zaragoza en el Hospital Real y General de Nuestra Señora de Gracia: Antonino DiANA, R.P.D. Antonini Diana Panormitani, Cler. Reg... Resolutiones Morales in Compendium redactae, \& in Ord. al phab. digestae..., Caesar Augustae, In typographica Officina Regii Nosocomii Deiparae de Gratia, 1635; pero en ese momento vivía todavía Pedro Blusón, por lo que el compromiso de Larumbe no tiene objeto para esa edición. Tampoco puede identificarse con la edición de Escuer de la quinta parte en 1642. Antonino DiANA, R.P.D. Antonini Diana...Clerici Regul. Resolutionum moralium quae quinque tomis continentur compendium auctore... Matthaeo Defendi, Caesaraugustae, apud Petrum Lanaja \& Lamarca..., a costa de Pedro Escuer..., 1642.

82 F. 60r.

83 Juan BIESCAS, R.P.M. Fr. Ioa[nnis] Biescas... Ordinis Praedicatorum... Tomus secundus Apologiae pro doctrina S. Thomae Ecclesiae sanctae Doctoris Angelici, Oscae, typis Ioannis Francisci à Larumbe..., 1641. 
mencionados. La edición de este segundo tomo vio la luz tres años después, en 1641, aunque los preliminares llevan fecha de 1638 o de1639. No obstante, un ejemplar de esta obra de 960 páginas en formato folio está compuesto de 240 pliegos para el texto y 5 más para las 20 páginas de los preliminares. Si la impresión de cada pliego costó 26 ss. la edición costó 6.240 ss., solo el texto, o 6.370 ss. incluídos los preliminares. A esto habría que añadir el papel y las encuadernaciones. De todo lo dicho, se puede deducir que las indicaciones con respecto al coste de esta edición en el Libro de cuentas resultan muy parciales, pero ayudan a comprender algunas magnitudes económicas de una edición de esta importancia.

i) Se mencionan 1 mano (25 pliegos) de Siete salmos de un pliego con un precio de 6 ss. ${ }^{84}$ Por lo que cada uno de los 25 ejemplares costaría unos 3 ds. Es otra obra que no se ha podido identificar. Por la descripción, parece tratarse de un impreso de carácter menor en el que cada ejemplar ocuparía un pliego. ${ }^{85}$ En 1621, unos pocos años antes, se imprime en Cuenca una edición que lleva el título de Siete salmos penitenciales de Fernando de Jesús. ${ }^{86}$ Esta obrita, que responde perfectamente al mismo aspecto que se refleja en el Libro solamente contiene 8 hojas en $8^{\circ}$, un pliego, por tanto. Se vuelve a mencionar otro envío mucho mayor, lo que justifica la suposición de una edición de Huesca de esta misma obra, en 1629. ${ }^{87}$ Se trata de una @ de 7 salmos que se envía a Alfay. En esta @ de papel entrarían unos 1.800 pliegos. ${ }^{88}$ Lo que representa un número notable de ejemplares de esta producción oscense de los que no se ha podido localizar ninguno en la actualidad.

j) En 1637 Juan Francisco Larumbe apunta, con motivo de tener constancia de ello, las conclusiones que se imprimen en el curso deste presente año de 1637 desde 8 de noviembre. ${ }^{89}$ En esta «memoria», cita 4 producciones, con diferencias apreciables. Las Sabatinas de artes, estaban impresas por parejas en un pliego, se emplean 16 manos (400 pliegos) lo que produce 800 ejemplares, su coste de impresión es de $2 £$ y 8 ss. (48 ss.) y de papel $1 £$ y 1 s. (21 ss.), un total de 69 ss. Nada se dice del coste de papel de las del Primer turno de Teología, cuyo coste de impresión es de $1 £$ y 2 ss. (22 ss.). Las del Turno de prima de Canones tienen el mismo coste de impresión, pero en papel se gastan 8 manos (200 pliegos), que darían lugar a 200 ejemplares, a 16 ds. cada mano de papel, que quedan en 10 ss y 8 ds. El coste total asciende a 32 ss. y 8 ds. Las del Turno de prima de Leyes, tienen un coste de impresión de $2 £$, 4 ss. (24 ss.) y nada se dice del coste del papel. No obstante, se añaden una serie de gastos suplementarios: tirar 8 manos

84 F. 161r.

85 Existe una Declaracion de los siete psalmos penitenciales, del agustino Pedro de VEGA, en tres partes de 1606, impresa por Carlos Lavayen a costa de Juan de Bonilla. Pero el número de pliegos de esta edición impide por completo su identificación.

86 FERNANDO DE JESÚs, Exposición de los siete salmos penitenciales del verdadero profeta David, Cuenca, Salvador de Viader, 1621 (Alfaro, 2002, p. 112).

87 F. $18 \mathrm{v}$.

88 Si los 25.100 pliegos enviados del libro de los Estados pesaron 14 @, en 1 @ de pliegos de papel entrarían casi 1.800 pliegos.

$89 \quad$ F. $101 \mathrm{v}$. 
(200 pliegos) más, esto es, 200 ejemplares; 5 tafetanes para imprimir en ellos algunas Conclusiones; tirar 300 láminas (denominación que suelen recibir los grabados calcográficos) tiene un coste de $3 £$ (60 ss.), a 3 ds. por lámina; y pegar las 300 láminas, de 4 ss. Se mencionan otros dos trabajos más, pero los costes no están tan precisados: unas Conclusiones extraordinarias y un tafetán y las Conclusiones de vispras de theologia. ${ }^{90}$

Como puede observarse, es una memoria contable referida a una única tipología de documentos, las Conclusiones. No se citan otros trabajos que, sin duda, debieron realizarse en la imprenta univeritaria para atender las necesidades de la Institución.

Tabla 3. Precios de venta y tiradas

\begin{tabular}{|c|c|c|c|c|c|}
\hline Denominación & Precio/resma & Pliegos & Ejs. & $\begin{array}{l}\text { Coste } \\
\text { total }\end{array}$ & $\begin{array}{l}\text { Precio } \\
\text { ejemplar }\end{array}$ \\
\hline Via Crucis & 15 rs./resma & 8,5 & 500 & 255 ss. & $6 \mathrm{ds}$ \\
\hline Silva de romances & & 14 & 602 & & 1 s. y 2 ds. \\
\hline Villacastines & 16 rs./resma & 26 & 900 & 1.500 & 1 s. y 7 ds. \\
\hline Destierros & & 12 & 350 & & $8 \mathrm{ds}$ \\
\hline $\begin{array}{l}\text { Exercicios de fr. } \\
\text { Luys }\end{array}$ & 16 rs./resma & 14 & 500 & 452 ss. & 9 ds. \\
\hline De usucap. & 12 rs./resma & $50 \mathrm{y}^{1 / 4}$ & 500 & $1.918 \mathrm{ss}$. & 4 ss. \\
\hline $2^{a}$ parte de Diana & 13 rs./pliego & 20 & & 920 ss & \\
\hline $2^{a}$ Parte de Biescas & $\begin{array}{l}26 \text { ss./pliego } \\
=13 \text { rs./pliego }\end{array}$ & 245 & & $6.370 \mathrm{ss}$ & \\
\hline 7 salmos & & 1 & $\begin{array}{l}1.800 \\
\dot{d} ?\end{array}$ & & $3 \mathrm{ds}$. \\
\hline Sabatinas de Artes & & $1 / 2$ & 800 & 69 ss & $1 \mathrm{~d}$. \\
\hline $\begin{array}{l}\text { Turno de prima de } \\
\text { canones }\end{array}$ & & 1 & 200 & $\begin{array}{l}32 \text { ss y } 8 \\
\text { ds }\end{array}$ & 2 ds. \\
\hline
\end{tabular}

Se puede apreciar una discreta oscilación en el coste del precio por resma de 4 rs. (8 ss.), ${ }^{91}$ pero ninguna variación cuando la unidad de impresión es el pliego, 26 ss. En realidad no existe una diferencia de unidad de medida, puesto que la tirada, cuando se pacta el precio por resma suele ser de 500 ejemplares por lo que pliego y

90 F. 102r.

91 Esperanza Velasco (1998, pp. 42-46, 49-50, 52 y 187), aprecia diferencias mayores en Zaragoza en la primera mitad del siglo XVII que van entre los 28 ss. por imprimir unos pliegos administrativos en 1632 a los 48 ss. por Jerónimo ZURITA, Los cinco libros primeros de la primera parte de los anales de la Corona de Aragon [tomo primero-sexto]. Impressos en Zaragoza en el Colegio de San Vicente Ferrer por Juan de Lanaja y Quartanet a costa de los Administradores del General [t. 1 y 5], por Iuan de Lanaja y Quartanet, a costa de los Administradores del General [t. 2-4, 6],1610, en 1609, pasando por los 36 ss. de la continuación de Bartolomé LEONARDO DE ARGENSOLA, Primera parte de los Anales de Aragon : que prosigue las del secretario Geronimo Çurita: desde el año 1516 del nacimiento de Nuestro Redentor En Çaragoça, por Iuan de Lanaja..., 1630, en 1627; y los 44 ss. de Jerónimo BATISTA DE LANUZA, Tomo primero [-quinto] de cinco que contienen las Homilias sobre los Euangelios de la Quaresma, En Zaragoça, por Iuan de la Naia y Quartanet ..., 1636, en 1633. Si bien en este caso, a diferencia del que tiene como objeto este trabajo, no siempre se trata del mimo taller tipográfico. 
resma se identifican, salvo en lo que pueda referirse a los ejemplares de capilla o de gracia. Por esta causa, no se siente obligado a indicar la tirada de la edición en los casos que presupuesta por pliego.

Pero lo más remarcable de todas estas noticias es que de 11 ediciones detectadas y mostradas en este cuadro solo 4 (el Manual de consideraciones de Villacatín, los Destierros de ignorancia, el De Usucapione de Asín y la Segunda parte de la Apología de Biescas) son conocidas. Bien es cierto que una buena parte son impresos menores, pero esto no quita para revelar una situación que muestra el gran tarbajo que queda por hacer.

\subsection{La venta de estampas}

Entre las actividades de la imprenta figuraba la producción y venta de stampas. Estas, como ocurre casi siempre con los libros, se venden y valoran en resmas impresas. La característica principal de las estampas es que el vuelto está en blanco por lo que no tienen retiración y tampoco lleva trabajo de composición, salvo que incorpore alguna línea de texto; y, si no precisa composición tampoco necesita corrección. Esto es, la impresión de una resma de estampas debería costar en tiempo mucho menos que la impresión de una resma de páginas de cualquier libro. La resma tampoco sirve como unidad de medida que pueda ayudar a la determinación del número de unidades (estampas) de que se trata. La resma, como se ha visto, es la unidad de medida del papel en pliegos, pero en un pliego pueden tener cabida uno, dos, tres, o más impresos mediante composiciones e imposiciones diferentes o jugando con el paso por la prensa en el blanco y la retiración de la misma media forma compuesta. ${ }^{92}$ Por esta causa, no es posible en todos los casos apreciar el número de estampas reales que se están poniendo en circulación.

En 1627 el procurador del Pilar recibe, por una parte, 3 resmas (1.500 pliegos) de estampas cuyo precio se estableció en 20 rs. (40 ss.) la resma, lo que hace un total de $6 £$ o 120 ss.; y, por otra, media resma más de estampas pequeñas por 9 rs. o 18 ss., esto es a 36 ss. la resma. El hecho de que se trate de estampas pequeñas, implica que en el pliego hay por lo menos dos estampas y que, seguramente, el comprador tendra que cortar el pliego para obtener las unidades correspondientes.

El mismo año una sirvienta del «cogedor» de Nuestra Señora del Pilar, Miguel Carrera, lleva para el mencionado Carrera, 3 resmas (1.500 pliegos) de estampas pequeñas y una resma (500 pliegos) de estampas de pliego. El propio Blusón le lleva una resma más de estampas pequeñas. ${ }^{93}$ Un total de 8,5 resmas, 4.250, pliegos de estampas de las que principalmente son estampas pequeñas, seguramente de medio pliego o cuarto de pliego, lo que aumentaría mucho el número de ejemplares producidos y enviados.

Nuevos apuntes sobre la venta de estampas se localizan en 1631. El mismo Miguel Carrera se lleva de la imprenta 3 resmas y 7 manos (1.675 pliegos) en un único viaje

92 Estos mecanismos de composición e impresión son empleados en las bulas de la Catedral de Huesca (Reyes, Pedraza, 2019).

93 F. 2r 
y, posteriormente, otra resma (500 pliegos) más. ${ }^{94}$ En ninguna de las dos entradas se dice nada al respecto del tipo de estampas y del precio de las mismas, pero suponen un total de 2.175 pliegos. De tratarse de estampas pequeñas se podría hablar de 4.350 en folio o medio pliego o de 8.700 si se trata de estampas con formato cuarto.

El 15 de agosto de 1632 un criado de Miguel Carrera retira 6 manos, 150 pliegos, de estampas pequeñas y con posterioridad su hija se lleva un encargo específico de 2 resmas (1.000 pliegos) de estampas pequeñas, media (250 pliegos) de estampas grandes y otra media (250 pliegos) de estampas de los 7 Dolores, 3 resmas en total cuyo precio está establecido en 18 rs. o 36 ss. por resma. Hacen un total de 108 ss.

En 1636, se reconoce una deuda de la Casa de Nuestra Señora de Monserrat de 8 resmas (4.000 pliegos) de imágenes pequeñas y de 2 resmas (1.000 pliegos) de grandes. A estas se añaden otras 5 manos (125 pliegos) de imágenes pequeñas. ${ }^{95}$

En el año siguiente, 1637, Benito Soler retira del taller 10 resmas (5.000 pliegos) de estampas grandes y pequeñas a 16 rs. (32 ss.) la resma que suponen 16 escudos o $16 £$ (320 ss.). A estas hay que añadir otras 2 resmas (1.000 pliegos) al mismo precio, esto es 32 rs., o $3 £$ y 4 ss. (64 ss.) por las 1.000 estampas. ${ }^{96}$ En estos últimos apuntes no se menciona la representación que figuraba en las estampas, que podría ser una única o tratarse de estampas con diferentes representaciones.

En este mismo año, 1637, Pedro de Zala, vicerrector de la Casa de San Antón, lleva 3 resmas (1.500 pliegos) de estampas cuyo coste había sido concertado con el impresor en 17 rs. (34 ss.) la resma. La suma total de estas estampas alcanza $5 £$ y 2 ss. (102 ss.). ${ }^{97}$ Parece lógico que, puesto que se trata de un pacto, las imágenes representadas en estos 1.500 pliegos sean precisamente las de san Antón.

El número total de resmas de estampas asciende a 16 resmas y 8 manos. Aunque todas tienen el mismo coste a la venta, 18 rs. o 36 ss., solo en el primero de los encargos se establece un precio algo superior al del resto de los mismos 20 rs. o 40 ss. Se diferencian, de esta manera 6 tipos de estampas:

$1^{\circ}$. Estampas de «a pliego», quizas con la representación de la Virgen del Pilar, ya que se envían a miembros relacionados con el Pilar, como su procurador o su cogedor. Tan solamente se retiran de este tipo una resma y media (750 pliegos) que harían 750 estampas. Se trataría, según parece, de grandes representaciones de la virgen.

2. Predominan en los encargos las estampas pequeñas, siendo las grandes o de a pliego excepcionales, como se ha dicho. No queda claro si estas estampas tienen formato folio o cuarto, por lo que es imposible calcular el número de ejemplares producidos. Se entregan un total de 14 resmas y 8 manos, 7.200 pliegos. Si se tratase de estampas en folio, serían 14.400 estampas; en cuarto, serían 28.800; y, si se tratase de estampas en formato octavo, serían 57.600 ejemplares. 
3. Estampas de la Virgen de los Siete Dolores, por último, de las que únicamente se llevan media resma (250 pliegos) al mismo precio que el resto de los productos de este tipo. De nuevo, existen los mismos problemas: el formato no está establecido en la documentación y tampoco se conocen ejemplares de las mismas.

4. En 1636, se reconoce una deuda de la Casa de Nuestra Señora de Monserrat de 8 resmas (4.000 pliegos) de imágenes pequeñas y de 2 resmas (1.000 pliegos) de grandes. A estas se añaden otras 5 manos (125 pliegos) de imágenes pequeñas. ${ }^{98}$

5. En el año siguiente, 1637, Benito Soler retira del taller 10 resmas (5.000 pliegos) de estampas grandes y pequeñas a 16 rs. (32 ss.) la resma que suponen 16 escudos o $16 £$ (320 ss.). A estas hay que añadir otras 2 resmas (1.000 pliegos) al mismo precio, esto es 32 rs., o $3 £$ y 4 ss. (64 ss.) por las 1.000 estampas. ${ }^{99}$ En estos últimos apuntes no se menciona la representación que figuraba en las estampas, que podría ser una única o tratarse de estampas con diferentes representaciones.

6. En este mismo año, 1637, Pedro de Zala, vicerretor de la Casa de San Antón, lleva 3 resmas (1.500 pliegos) de estampas cuyo coste había sido concertado entre ambos a 17 rs. (34 ss.) la resma. La suma total de estas estampas alcanza $5 £$ y 2 ss. (102 ss.). ${ }^{100}$ Parece lógico que, puesto que se trata de un pacto y concierto, las imágenes representadas en estos 1.500 pliegos de estampas sean precisamente las de san Antón.

La impresión xilográfica requería tacos de madera de un tamaño proporcionado con la representación. Hacia 1631 Blusón reconoce que ha comprado a Jacques Borbón unas tablas para imprimir estampas:

Primo, cien reales de resta que le quede deviendo de las tablas para imprimir imágenes de Nuestra Señora del Pilar de Caragoça y otra de Nuestra Señora de Monserrate que le compre a su merced en 20 L. ${ }^{101}$

La nota del Libro parece apuntar a que el número de tablas que compra el impresor asciende a tres, unas tablas para imprimir imágenes de Nuestra Señora del Pilar de Caragoça y otra de Nuestra Señora de Monserrate. Las tablas del Pilar deberían dar lugar a imágenes de pliego y pequeñas, pero nada se dice de las de Monserrat de las que no ha indicado ninguna producción en el Libro de cuentas, salvo que es una única tabla cuyo coste fue de $20 £$ (400 ss.). Lo que más resalta de esta anotación es lo costoso que resultan estas tablas. Nótese que los tres tacos xilográficos tallados, si la suposición es correcta tienen un coste de $60 £$ (1.200 ss.).

Se puede apreciar un resumen esquemático sobre la producción de las estampas en el cuadro siguiente:

\footnotetext{
F. 20r.

F. 1v.

F. 3r.

101 F. 25v.
} 
Tabla 4: Precios de venta de estampas

\begin{tabular}{|c|c|c|c|c|}
\hline Año & Tipo & Cantidad & Precio / resma & Precio total \\
\hline 1627 & & 3 resmas & 40 ss & 120 ss. \\
\hline 1627 & Pequeñas & $1 / 2$ resma & $36 \mathrm{ss}$ & $18 \mathrm{ss}$. \\
\hline 1627 & $\begin{array}{l}\text { Pequeñas } \\
\text { A pliego }\end{array}$ & $\begin{array}{l}3 \text { resmas } \\
1 \text { resmas }\end{array}$ & & \\
\hline 1627 & Pequeñas & 1 resmas & & \\
\hline 1631 & & 3 resmas, 7 manos & & \\
\hline 1631 & & 1 resma & & \\
\hline 1632 & Pequeñas & 6 manos & & \\
\hline 1632 & $\begin{array}{l}\text { Pequeñas } \\
\text { Grandes } \\
7 \text { Dolores }\end{array}$ & $\begin{array}{l}2 \text { resmas } \\
1 / 2 \text { resma } \\
1 / 2 \text { resma }\end{array}$ & 36 ss. & $108 \mathrm{ss}$. \\
\hline 1636 & $\begin{array}{l}\text { Montserra } \\
\text { t grandes } \\
\text { Montserra } \\
\text { t pequeñas }\end{array}$ & $\begin{array}{l}8 \text { resmas } \\
2 \text { resmas, } 5 \text { manos }\end{array}$ & & \\
\hline 1637 & $\begin{array}{l}\text { Grandes y } \\
\text { pequeñas }\end{array}$ & 12 resmas. & 32 ss. & 384 ss. \\
\hline 1637 & San Antón & 3 resmas & 34 ss & 102 ss. \\
\hline TOTAL & & 42 resmas, 3 manos & & \\
\hline
\end{tabular}

En total Zamora y Carrera adquieren de la imprenta de Blusón casi 20 resmas (10.000 pliegos) de estampas, de las que la inmensa mayoria son de la Virgen del Pilar de Zaragoza. Resulta, sin embargo, llamativo el hecho de que estas estampas de la Virgen del Pilar no se confeccionen en Zaragoza sino en Huesca.

La casa de Montserrat en 1636 retira por su procurador 11,5 resmas de imágenes grandes y pequeñas (5.750 pliegos) y otros objetos propios de librería como 3 libros blancos y «mandatos». ${ }^{102}$ Se deduce del comprador que la representación de las estampas es la de la Virgen de Montserrat.

La casa de san Antón en 1637 compra 3 resmas (1.500 pliegos) de imágenes por medio de Pedro de Zala a 17 reales la resma. ${ }^{103}$ Aunque no se dice qué representación tienen las estampas parece lógico pensar que se trata de san Antón.

Finalmente, en el mismo año, Benito Soler, cuya profesión se omite en el documento y al que no se ha localizado en otras fuentes, compra 12 resmas a 16 rs (32 ss.) la resma de estampas. En este caso no se dice nada en Libro al respecto de la representación que se había impreso en las estampas. Además, compra 4 libros blancos a 4 ss. cada uno y el día 20 de septiembre siete manos de carteles privilegios diferentes. ${ }^{104}$

Se trata de una actividad residual de la imprenta. Según se deducía de las anotaciones hechas por Blusón estas producciones responden a peticiones o encargos previos de los compradores, especialmente cuando se trata de Instituciones. Pero el caso de Soler es diferente, parece que adquiere estampas e impresos diferentes como

\footnotetext{
102 F. 20r.

103 F. 3r.

104 F. 1V.
} 
si de un «merchante» o "papelista» se tratase. En cualquier caso en el Libro se comercia con 42 resmas y 3 manos de estampas (21.750 pliegos). Pues bien no se conoce en la actualidad ninguna estampa de las citadas en el documento.

\subsection{La estampación calcográfica}

Se hace mención también a la estampación calcográfica en sendas ocasiones en el Libro de cuentas: la primera vez al fijar la contabilidad de la edición de Resoluciones morales de Antonino Diana de 1635, 500 estampas para la portada, y, la segunda, en la de las Conclusiones del año 1637 donde se mencionan 300 estampas.

El coste de estas láminas es considerable. De tirar las 500 láminas se cobran 50 ss., 10 ss. por centenar, y de de tirar las 300 se pagan $3 £$ (60 ss.), 20 ss. por centenar de láminas, justo el doble. También se incluye el pago por poner el escudo en las Conclusiones, que asciende a 16 ss. ${ }^{105}$

Estos costes, perfectamente independizados permiten confirmar que, aunque se disponía de la posibilidad de incorporar este tipo de reproducciones en los libros. Al coste de las láminas espreciso añadir el coste de pegarlas que se establece en 4 ss. por pegar las 300 láminas ya citadas en las Conclusiones.

Las estampas son un producto muy rentables. Los 900 ejemplares de los Villacastines ${ }^{106}$ que se entregan a Felipe Bonilla el 12 de noviembre de 1627, se vendieron a 32 ss. por cada resma impresa, mientras que la resma de estampas se vende, como poco, a 36 ss. sin tener que componer, corregir ni retirar.

\subsection{Las encuadernaciones}

Los libros se comercializaban principalmente en rama, esto es, en pliegos, generalmente ya plegados según el formato decidido para el libro, pero sin encuadernar. Sin embargo, algunos ejemplares se encuadernaban para su venta, bien porque así lo pidiera el editor o bien porque así era más fácil colocarlos en el mercado.

Blusón tenía concertados los precios de las encuadernaciones desde el 2 de enero de 1632 con el librero Baltasar Martínez ${ }^{107}$ de la siguiente manera:

1. En octavo, a 6 ds.

2. En doze, a 6 ds.

3. En 16, a tres $d s$.

4. La dozena de Doctrinas y 7 Psalmos a ocho ds.

Los materiales de encuadernación corren por cuenta del encuadernador y por tanto su coste estaba incluido en el precio estipulado.

105 Agulló (2009, doc. 1.261) cita por el pago de 290 y de 648 estampas de marca mayor por un precio de $1 \mathrm{r}_{\mathrm{c}}$ cada una, 1 s. y $1 / 2$ d. cada estampa en moneda aragonesa.

106 F. 16v. Tomás de VILLACASTín, Manual de consideraciones, y exercicios espirituales, para saber tener oración mental, En Huesca, por Pedro Bluson, impresor de la Universidad, 1627

107 F. 167v. Es la última del documento. 
Los impresores tiene que encargar y adquirir las encuadernaciones fuera del taller, que, como es lógico, solo se dedicaba a imprimir. En 1636 anota el coste que le ha supuesto la encuadernación de un ejemplar del $3^{\circ}$ y $4^{\circ}$ tomo de las «Decisiones» de $\operatorname{Sese}^{108}$ que le ha hecho Pedro Escuer. Se trata de la encuadernación en un único volúmen de dos ediciones diferentes, aunque del mismo impresor y año, impresas por Juan de Larumbe y editadas por Juan de Bonilla y Pedro Bono. ${ }^{109}$

El 5 de marzo de 1639 Larumbe pasa cuentas con Jerónimo Assín por la publicación de su libro llegando a determinar que le debe $22 £$ (440 ss.) que se cubren con lo que le adeuda por la encuadernación de 23 ejemplares que están en poder de Juan Francisco Larumbe. ${ }^{110}$ La encuadernación de cada uno de estos 23 ejemplares costó en torno a 19 ss. Mucho más caros que los precios concertados por Blusón unos años antes con el librero Baltasar Martínez, pero nada se dice del tipo de encuadernación ${ }^{111}$ Seguramentee las encuadernaciones de Martínez serían trabajos en pergamino flexible mientras que las encuadernaciones de Assín, para regalar su obra, serían más lujosas y, en consecuencia, más costosas.

\section{A modo de conclusión}

El Libro de cuentas de Pedro Blusón y Juan Francisco de Larumbe es, hasta el momento, el instrumento más antiguo de este tipo encontrado, lo que le dota de notable importancia para la historia del libro hispano. Es mucho lo que se puede obtener de él sobre los procedimientos, usos, artífices... de los impresores en un momento esencial del mundo del libro, el Siglo de Oro Español, incluida la contabilidad de la imprenta.

De su análisis, se observa una estrecha relación con la próxima Zaragoza por lo que se refiere a la provisión de pólizas y de la localidad de Villanueva de Gállego para la proveer de papel. También es Zaragoza la principal receptora de algunas de las producciones, junto con el propio comercio local y el próximo de Barbastro. Todos estos factores hacen necesario tener en cuenta el coste de transporte, de personas y de mercancías. El trasporte de una persona por por trayecto es de $8 \mathrm{ss}$. y el de una arroba de peso de mercancía de 1 ss. y 4 ds., el de la bala de papel asc iende a 4 ss., lo que equivale a 3 arrobas de peso.

Se han obtenido referencias fiables y de primera mano sobre los precios de fundiciones y tacos xilográficos y del papel de la tierra y los papeles especiales. Una fundición tiene un coste importante que varía según el cuerpo y la cantidad de tipos de

108 F. 45r.

109 José de SESSE, Decisionum sacri senatus regii Regni Aragonum et Curiae Domini Iustitiae Aragonum causarum civilium tomus tertius... auctore... Iosepho de Sesse... Ordinis Minorum, Caesaraugustae, ex typographia Ioannis a Larumbe, expensis Ioannis à Bonilla \& Petri Bono, expensis Regni, 1627; y José de SESSE, Decisionum sacri senatus regii regni Aragonum... Tomus quartus in quo ad sunt duo indices... auctore domino Iosepho de Sesse... ordinis Minorum S. Francisci de Paula, Caesaraugustae, ex typographia Ioannis a Larumbe, expensis Ioannis a Bonilla [et] Petri Bono, 1627.

110 F. 23v de numeración actual.

111 En 1604 Juana Montoya, librera del Reino, recibe de los Diputados del Reino de Aragón 336 ss. por encuadernar 28 volúmenes de los Indices de los Anales de Zurita, por tanto, a 12 ss. por volumen (Velasco, 1998, pp. 40-41). 
cada suerte, que decide el impresor, entre 300 y unos 600 ss. Pero el precio de una fundición podría estar al mismo nivel que el de un taco xilográfico. El papel de la tierra se paga a 14 ss. la resma, el de marca mayor se paga un 60 por ciento más caro. Los papeles de más calidad importados pueden llegar a costar el doble de estos precios.

Se ha observado que hay una tendencia a concertar unos primeros contratos con los oficiales de la imprenta por debajo del salario medio, que puede fijarse en los 60 ss. No obstante, el salario está en función de lo pactado entre los contratantes sin que haya unos límites fijos. Las diferencias entre los jornales de los trabajadores de la prensa y los de las cajas es apreciable, aunque, por lo dicho anteriormente, puede llegar an algunos contratos a ser inexistente.

Se aprecia que se tiende hacia tiradas bajas, incluso de 500 ejemplares, salvo en el caso de los impresos menores. El precio de la impresión por resma oscila levemente entre los 12 rs y los 16 . El coste de una tirada de un libro de 500 ejemplares en $4^{\circ}$ de unas 400 páginas con una calcografía en la portada vendría a ser de 1.918 ss. No es posible conocer los gastos derivados de los procesos administrativos y de edición que pueden alargarse mucho en el tiempo.

Se ha observado que las imprentas también se dedican a la producción de estampas, cuya impresión ofrece una mayor rentabilidad que la de otros productos: el precio de una resma de estampas oscila entre los 32 y los 40 ss.

Por último, el Libro define los precios de los principales tipos de encuadernaciones que se enviaban a talleres especializados para su elaboración. Las encuadernaciones en $16^{\circ}$ se gan a 3 ds. las encuadernaciones en $12^{\circ}$ y $8^{\circ}$ a 6 ds.

\section{Referencias bibliográficas}

Agulló y cobo, M. (1974). Más documentos sobre impresores y libreros madrileños de los siglos XVI y XVII. Anales del Instituto de Estudios Madrileños, 10, 1-15.

Agulló y cobo, M. (2009).La imprenta y el comercio de libros en Madrid: (siglos XVIXVIII). [Tesis Univ. Complutense], en UNIVERSIDAD COMPLUTENSE, E-Prints Complutense: el repositorio de la producción académica en abierto de la UCM [En línea]. Madrid: Universidad Complutense, 2005- . https://eprints.ucm.es/8700/. [Consulta: 16/04/2020].

Alfaro torres, P. (2002). La imprenta en Cuenca (1528-1679). Madrid: Arco Libros.

Dekker, R. (ed) (2002). Egodocuments and History: Autobiographical Writing in its Social Context since the Middle Ages. Hilverum: Verloren.

Hidalgo brinquis, M.C. (2013). La fabricación del papel en España e Hispanoamérica en el siglo XVI, en Actas del X Congreso de Historia del Papel en España. Madrid: Asociación Hispánica de Historiadores del Papel.

Lara izquierdo, P. (1984). Sistema aragonés de pesas y medidas: la metrología histórorica aragonesa y sus relaciones con la castellana. Zaragoza: Guara.

Lucía megías, J.M. (2006). Imprenta, libros y lectura en la España del Quijote. Madrid: Imprenta Artesanal.

Moll, J. (2003). El taller de la imprenta. En infantes, v., lopez, f., botrel, J.-F. (eds.), Historia de la edición y de la lectura en España, 1472-1914. Madrid: Fundación Germán Sánchez Ruipérez, pp. 31-38. También: En Biblioteca Virtual Miguel de Cervantes. 
Alicante: Biblioteca Virtual Miguel de Cervantes. www.cervantesvirtual.com/obra/eltaller-de-la-imprenta/ [Consulta: 16/04/2020].

Mouysset, S. (2007). Papiers de famille: introduction à l'étude des livres de raison. France $X V e-X X e$ siècle. Rennes: Presses Universitaires de Rennes.

Reyes gómez, f., pedraza gracia, M.J. (2019). Las indulgencias para la catedral de Huesca, un ejemplo para el estudio de la edición de bulas incunables. Revista General deInformación y Documentación, 29 (2), 399-411.

Tejeda, G. (1546). Suma de aritmética practica. Valladolid: Francisco Fernández de Córdoba.

University of oxford (2019), 15cBooktrade. Oxford: University of Oxford, 2014. <http://15 cbooktrade.ox.ac.uk/project/>. [Consulta: 10/03/2019].

Velasco de la peña, E. (1998). Impresores y libreros en Zaragoza (1600-1650). Zaragoza: Institución fernándo «el Católico».

Wilkinson, a.s., ulla lorenzo, A.(2015). Iberian Books (1601-1650). Leiden: Brill. 